\title{
Scientists have a responsibility to the public
}

\section{Anthony Tabet ${ }^{1, *}$}

\section{HIGHLIGHTS}

Scientists should make their voices heard on matters concerning their expertise that affect the general public in a jargon-free way

The training of most scientists in the United States is largely supported by significant public funds. The public expects a return on that investment. Scientists therefore have an obligation to engage with and inform the public on how emerging technologies and challenges will affect our communities. In founding the MIT Science Policy Review, we seek to provide a platform to fulfill such a public obligation.

$\mathrm{n}$ the United States, most scientists are trained at universities with strong financial support from the government[1]. Academic institutions hire professors who run research laboratories predominantly funded by grants from federal agencies (Fig. 1). These grants provide the supplies used in the labs, pay the salaries and tuition of the graduate students seeking doctoral degrees, and pay the salaries of postdoctoral fellows seeking additional scientific training. Most of these scientific research grants come from the National Science Foundation (NSF), the National Institutes of Health (NIH), the Department of Defense (DOD), and the Department of Energy (DOE)[1]. At MIT, a research laboratory in science or engineering often pays nearly $\$ 500,000$ to train a single $\mathrm{PhD}$-level graduate student. A majority of those funds usually comes from federal grants.

This money is not free. It comes with an obligation for scientists to inform and engage with the public on matters related to their expertise that affect the well-being of our communities. At the MIT Science Policy Review, we believe this obligation goes beyond publishing a research paper filled with jargon directed towards other scientists in a particular field. The "broader impacts" should include communication that is jargon-free, on-the-record, and accessible. This communication should also draw attention to the potential benefits and risks of new technologies, and their impact on society. The Review is written by scientists for a non-scientist audience and will always be free to read. In founding the

\footnotetext{
${ }^{1}$ Founder and Editor-in-Chief, MIT Science Policy Review, Cambridge, MA *Email: tabet@mit.edu
}

The author declares no conflict of interest.

(C) 2020 The Author(s)
Review, we sought to create a platform that expands the ability for scientists to engage with non-scientist stakeholders in the science policy process, including the general public and lawmakers. This is one step toward an important cultural change that needs to occur in science to build a more engaging and accessible scientific process, and a more informed public.

The challenges of the 21st century are deeply technological and multi-faceted. Highly infectious pathogens such as the novel coronavirus pose enormous threats to global health and the global economy, and rapid ( $<12$ months) vaccine development and scale-up remain technologically challenging. Climate change is an existential threat that has no comfortable solution and requires immediate and drastic policy action to tackle. Damage to our oceans due to environmental pollution is threatening food supplies. Microbes resistant to our last line of antimicrobial defenses are beginning to emerge and are a public health emergency in waiting. We are entering the fourth industrial revolution and automation will upend entire industries and potentially leave millions of people unemployed and left behind. World governments are not fully prepared to address or deal with the repercussions of gene-edited human embryos. Major advances in artificial intelligence by governments and private corporations are threatening privacy and civil liberties. Space is becoming more accessible, commercial, and militarized. Meanwhile, disinformation campaigns on unregulated social media platforms are making us more partisan, less informed, and less prepared to address the great challenges of this century.

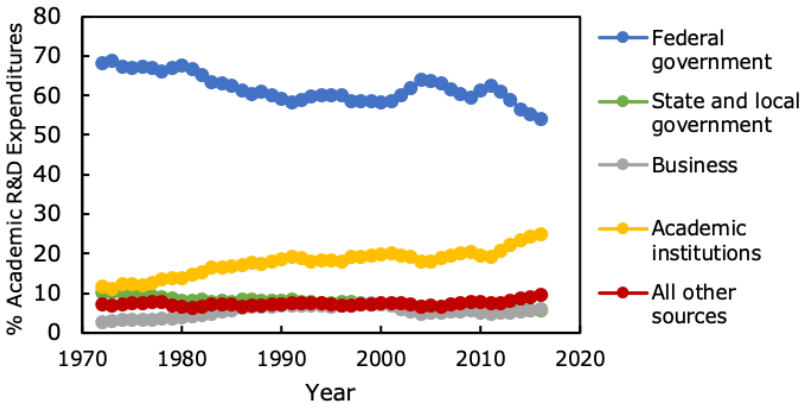

Figure 1: Percent of university research and development funding from the federal government and other sources. Data: National Science Foundation. 
Now, more than ever, we need an informed citizenry and political class. Few issues are black and white, and the reduction of our public discourse to malicious 280 character jabs threatens our ability to meaningfully take on hard issues. We believe the challenges of the 21 st century will require scientists to communicate more accessibly, directly, and thoughtfully with the general public and our political leaders. The Review will serve that purpose.

\section{Acknowledgements}

The author would like to thank the MIT Alumni Association, MIT Libraries, and the MIT Science Policy Initiative for providing advice and encouragement in creating the Review. The author would also like to thank the founding team, editors, authors, and advisory board members for all their efforts in building this organization.

\section{Citation}

Tabet, A. Scientists have a responsibility to the public. MIT Science Policy Review 1, 1-2 (2020).

\section{Open Access}

\section{(c) (i)}

This MIT Science Policy Review article is licensed under a Creative Commons Attribution 4.0 International License, which permits use, sharing, adaptation, distribution and reproduction in any medium or format, as long as you give appropriate credit to the original author(s) and the source, provide a link to the Creative Commons license, and indicate if changes were made. The images or other third party material in this article are included in the article's Creative Commons license, unless indicated otherwise in a credit line to the material. If material is not included in the article's Creative Commons license and your intended use is not permitted by statutory regulation or exceeds the permitted use, you will need to obtain permission directly from the copyright holder. To view a copy of this license, visit http: //creativecommons.org/licenses/ by $/ 4.0 /$.

\section{References}

[1] Data on the Financial and Infrastructure Resources for Academic R\&D, National Science Foundation (2018). 